\title{
Chemical and Antioxidant Potential of Agaricus sylvaticus Mushroom Grown in Brazil
}

Joice Vinhal Costa ${ }^{1 *}$, Maria Rita Carvalho Garbi Novaes ${ }^{2}$ and Eduardo Ramirez Asquieri ${ }^{3}$

${ }^{1}$ Professor, Instituto Federal Goiano- Campus Urutaí, Brazil

${ }^{2}$ Professor, School of Medicine, Escola Superior de Ciências da Saúde -ESCS-FEPECS; Universidade de Brasilia - UnB, Brazil

${ }^{3}$ Professor, School of Pharmacy, Universidade Federal de Goiás - UFG, Brazil

\begin{abstract}
The chemical characterization of Agaricus sylvaticus (A. sylvaticus) cultivated in Brazil is necessary to determine nutritional and pharmacological substances in order to guarantee its safe use as food or herbal medicine. The objective of this study was to determine the chemical composition and assess the antioxidant potential of $A$. sylvaticus fungi grown in Brazil. Through this study it was able to observe the rich chemical composition of $A$. sylvaticus, highlighting the variety and amount of minerals as well as the high protein content of this fungus. It was also observed the great antioxidant potential of the aqueous, alcoholic and ethereal $A$. sylvaticus mushroom extracts, emphasizing the alcoholic extract, which testifies the extraordinary benefits of this fungus in diet, since antioxidants prevent premature aging and various types of cancer as well. The composition of $A$. sylvaticus mushroom displayed differences when compared to the chemical composition of the same fungus in other studies and with other Agaricales fungi.
\end{abstract}

Keywords: Chemical composition; Medicinal mushroom; Potential antioxidant

Abbreviations: \%: Percentage; Wavelengths; A. sylvaticus : Agaricus sylvaticus; ABTS: 2,2-azinobis-3-ethylbenzothiazoline-6-sulfonic acid-diamonic; AOAC: Association of Official Analytical Chemists; BHT: di-terc-butil metil fenol; DPPH: 2.2-difenilpicril-hydrazyl; $\mathrm{HCl}$ : Chloridric acid; HPLC: High performance liquid chromatography; $\mathrm{NH}_{4}^{+}$: Ammonium; PUFA: Polyunsaturated fatty acids; $\mathrm{R}^{2}$ : Correlation coefficient; TBHQ: Terc butil hidroquinona

\section{Introduction}

Mushrooms are considered nutraceuticals or functional foods by many clinicians and researchers, a fact that has also stimulated the search by Brazilian producers for more advanced production techniques along with introduction of new species [1].

According to Urben [3], there is great genetic variety of native Agaricus genus mushrooms cultivated throughout the world. Strains produced by these mushrooms result from the kind of substrate or compost used, climatic conditions, cultivation area and genetic mutation that can occur naturally or artificially.

Mushrooms are highly nutritious foods, having high amounts of protein, equivalent to meat, eggs and milk, much higher than vegetables and fruits. They contain vitamins such as thiamine, riboflavin, ascorbic acid (Vitamin C), erbocalciferol (Vitamin D2), and a high percentage of minerals like calcium, iodine and phosphorus, besides considerable amounts of fiber [2].

Chemical studies have revealed that the high concentration of nutrients and active ingredients in mushrooms is directly related to the type of lineage used, which requires specific conditions or several factors, such as: A) nutritional factors (substances essential for development: carbon, nitrogen, vitamins and minerals), B) abiotic factors (moisture content of compost and cover, temperature, light, oxygen, chemicals in air, $\mathrm{CO}_{2}$ ), $\mathrm{C}$ ) and biotic factor (virus, bacteria, actinomycetes, fungi, nematodes, insects, mites and genetic), D) genetic factors (natural or artificial); E) processing factors (harvest, drying/dehydration and storage) [3].

Mushrooms have been used for therapeutic prevention of various diseases, in the form of drugs and/or functional foods [4]. In Brazil, despite the low consumption of mushrooms by the population, Agaricus genus fungi are becoming very popular due to attributed medicinal properties. There are several studies that report the effects of A. sylvaticus (Sun mushroom) on various diseases and these properties may also be associated to the presence of bioactive compounds with medicinal value, such as phenolic compounds, polyketides, terpenes and steroids recognized as excellent antioxidants [5].

According to Elmastas et al. [6], phenolic compounds seem to be the main component responsible for the antioxidant activity in mushroom extracts. According to Tsai et al. [7], the antioxidant properties of Agaricus blazei may be associated with its high concentration of tocopherols.

The aim of this study was to evaluate the chemical composition of dehydrated A. sylvaticus fungus with respect to protein, lipids, carbohydrates, dietary fiber, minerals, liposoluble vitamins and vitamin $\mathrm{C}$ as well as determine the antioxidant potential of ether, alcoholic and aqueous extracts obtained from this mushroom.

\section{Materials and Methods}

\section{Evaluation of chemical composition}

In this laboratory based experimental study, samples of dehydrated A. sylvaticus (Sun mushroom) mushroom were obtained from a producer in the State of Minas Gerais. Mushrooms were crushed in a Willey type grinder, Model ET-648, Brand Tecnal to allow greater extraction of components. Physical and chemical analysis was performed at the Physical Chemistry Laboratory of "Centro de Pesquisa em Alimentos", School of Veterinary Medicine (accredited

*Corresponding author: Joice Vinhal Costa, Professor, Instituto Federal GoianoCampus Urutaí, Brazil, Tel/Fax: 55 -(64)3465-1900; E-mail: joicevinhal@gmail.com

Received January 21, 2011; Accepted March 09, 2011; Published March 14 2011

Citation: Costa JV, Garbi Novaes MRC, Asquieri ER (2011) Chemical and Antioxidant Potential of Agaricus sylvaticus Mushroom Grown in Brazil. J Bioanal Biomed 3: 049-054. doi:10.4172/1948-593X.1000042

Copyright: (C) 2011 Costa JV, et al. This is an open-access article distributed under the terms of the Creative Commons Attribution License, which permits unrestricted use, distribution, and reproduction in any medium, provided the original author and source are credited. 
by the Ministry of Agriculture, Livestock and Supply) and the Food Biochemistry Laboratory, School of Pharmacy, Universidade Federal de Goiás - UFG from March to June 2010

\section{Moisture evaluation}

Moisture evaluation was performed in duplicate with dehydrated A. sylvaticus fungus, applying the official method for moisture rating, using a kiln at $105^{\circ} \mathrm{C} \pm 3^{\circ} \mathrm{C}$ for 24 hours, established by the Ministry of Agriculture, Livestock and Supply, determined by the Association of Official Analytical Chemists [8].

This methodology quantifies the water withdrawn from the product by heating process, whereas the moisture content is calculated by the weight difference of the sample at the beginning (100\%) and at the end of the process $\left(100 \%-\%\right.$ water evaporated at $\left.105^{\circ} \mathrm{C}\right)$. This difference reflects the moisture of the sample under analysis.

First the sample was weighed (approximately $5 \mathrm{~g}$ ) and placed in a kiln at $105^{\circ} \mathrm{C}$ until its weight remained constant. After two weightings at intervals of five hours each, weight was observed to be constant. Next the sample remained in a desiccator in order to lower the temperature (up to room temperature) and was then weighed to check moisture content.

\section{Ash evaluation}

Ash evaluation of dehydrated A. sylvaticus fungus was performed by calcining the sample in furnace FDG Brand, Model 3P-S 7000, at $550^{\circ} \mathrm{C}$ for 12 hours, according to the official method of AOAC [8]. Through this technique it is possible to determine the total ash produced using the heat in a muffle furnace, where there is total destruction of organic matter present in the sample, leaving only those minerals present.

A sample of approximately $2 \mathrm{~g}$ of $A$. sylvaticus mushroom was weighed in a porcelain crucible, which had previously been incinerated with the aid of Bunsen burner, cooled and weighed. Then the set (sample + crucible) was incinerated in a muffle furnace, first at lower temperature and then at $550^{\circ} \mathrm{C}$. After incineration, the set was removed from the flask, placed in a desiccator to cool off and weighed when it reached room temperature. The amount of ash in the sample was detected from the weight difference between the weight of the set and the weight of the empty crucible.

The mushroom ash sample served as a starting point for analyzing specific minerals.

\section{Evaluation of minerals}

To determine the minerals, an atomic absorption spectrometry was used in spectrometer GBC Brand, Model 932AA. Duplicate analyses were performed. The principle of this technique is based on measuring the absorption of electromagnetic radiation intensity, from a primary source of radiation by gaseous atoms in ground state. It was possible to search for iron, zinc, manganese, sodium, potassium, cobalt, copper, calcium and magnesium, as these tests were performed in a laboratory where there were specific cathode lamps for each of these minerals.

\section{Protein evaluation}

For protein grading the Kjedahl method was used following the AOAC [8] methodology. Total nitrogen was obtained from the sample which, through calculation was transformed into protein Nitrogen considering that each $100 \mathrm{~g}$ of protein contains an average $16 \mathrm{~g}$ of nitrogen. Therefore we used a 6.25 correction factor, which was multiplied by the total Nitrogen percentage of the sample, which corresponded to the protein percentages [9].
To develop this methodology we used a Nitrogen distiller Brand Tecator, Kjeltec System Model 1026. Protein analysis involved three phases. In the first phase the nitrogen in the sample was transformed into ammonium $\left(\mathrm{NH}_{4}^{+}\right)$through acid digestion of organic matter, starting from $0.1 \mathrm{~g}$ of Degreased Dry Matter. In the second phase, separation was obtained by means of distillation and in the third phase, dosage by titration with $\mathrm{HCl} 0.02 \mathrm{~N}$.

\section{Evaluation of lipids}

The amount of lipids present in the sample of the A. sylvaticus mushroom was obtained through continuous extraction with a Soxhlet device, Brand Gerhardt, Soxtherm Model 2000, using sulfuric ether as solvent, which has a boiling point of approximately $35^{\circ} \mathrm{C}$. After extraction, the solvent was evaporated using a Rotavapor and lipid fraction was determined gravimetrically. After 24 hours, we obtained the average weight of lipid fraction. The extracted oil was stored at $10^{\circ} \mathrm{C}$ for later chromatographic analysis of fat soluble vitamins.

\section{Evaluation of total dietary fiber}

The methodology for the evaluation of total dietary fiber of $A$. sylvaticus fungus was proposed by AOAC [10], whose principle is based on the sequential enzymatic digestion of dehydrated mushroom sample, in duplicate, with thermostable alpha-amylase, protease and amyloglucosidase. The digested sample was then treated with alcohol to precipitate the soluble fiber before filtering, and the residue was washed with alcohol and acetone, dried and weighed.

\section{Carbohydrate evaluation}

The evaluation of carbohydrates was calculated by the difference, using rates obtained by the analysis of moisture, fixed mineral residue, proteins and lipids, following methodology recommended by AOAC [11]

\section{Evaluation of fat-soluble vitamins}

Fat-soluble vitamins were determined by high performance liquid chromatography (HPLC), and the performance of duplicate analysis. The principle of this technique evaluates the extraction of active compounds of vitamins studied and their conversion in free form in chloroform solution for later evaluation.

For this analysis, it was used as sample the oil obtained in lipid analysis through Soxhlet extraction. It was used liquid chromatography, Gilson brand, with a stationary phase column E-18, column $10 \mathrm{~cm} / 4.6$ $\mathrm{mm}$ and particles of $5 \mathrm{micras}$. For the mobile phase was used a methanol and isocratic working system with $100 \%$ of methanol and $1 \mathrm{~mL} / \mathrm{min}$ flow. Variable wavelengths $(\lambda)$ were used for each vitamin studied, as shown in Table 3.

\section{Vitamin C cvaluation}

Vitamin C evaluation was performed in triplicate, following the Tillmans Method starting from titration of a standard solution of ascorbic acid and oxalic acid solution with DCFI solution (2, 6-dichlorophenol indophenol sodium), and the solutions used were prepared as described by the Adolfo Lutz Institute (1995) for the Tillmans Method. To determine Vitamin C, it was obtained an aqueous, non fractioned extract of $A$. sylvaticus mushroom by diluting dried mushrooms ground in water, kept under agitation at room temperature for one hour.

\section{Evaluation of antioxidant potential}

The antioxidant potential of A. sylvaticus mushroom was determined following the methodology used by Borguini [12]. In 
order to avoid interference of light in the sample, the experiment was conducted using material covered with aluminum foil. It was obtained the ether, alcoholic and aqueous extracts from the mushroom. First it was obtained the ether extract by diluting $2.5 \mathrm{~g}$ of ground mushroom in $50 \mathrm{~mL}$ of ethyl ether. From non-filtered residue and therefore etherinsoluble, it was obtained the alcoholic extract by adding ethanol at 1:20 ratio (residue weight: volume of alcohol). And finally, it was obtained the aqueous extract by adding water to the non-filtered residue from the previous step and also adding distilled water at 1:20 ratio (residue weight: water volume).

BHT was used as a standard antioxidant and DPPH as an oxidant. The antioxidant activity of mushroom extracts was determined by DPPH (2.2-difenilpicril-hydrazyl) described by BRAND-WILLIAMS et al. [13]. DPPH is a stable free radical which accepts an electron or hydrogen radical to become a stable diamagnetic molecule, and thus, is reduced in the presence of an antioxidant.

Absorbance decrease was monitored at $517 \mathrm{~nm}$ in a spectrophotometer Model SP-220, Biospectro brand, at intervals of 0 , $1,2,3,4,5,10,15$ and 20 minutes of reaction. The values observed in the spectrophotometer were converted to a percentage scale, which indicates $0 \%$ - no inhibition of free radical production, and $100 \%$ indicates complete inhibition of the same.

\section{Quantification of total polyphenols}

Concentration of total polyphenols was determined by colorimetric method described by Singleton and Rossi [14], using the Folin Ciocalteau reagent.

For quantification of total polyphenols in the sample, a standard curve of gallic acid solution at concentrations of $0.01 \mathrm{mg} / \mathrm{mL}$ to $0.06 \mathrm{mg} /$ $\mathrm{mL}$ was used. The correlation coefficient $\left(\mathrm{R}^{2}\right)$ was calculated, resulting in $\mathrm{R}^{2}=0.99775$ to a $5 \%$ level of significance. This test was performed in triplicate, by using the ether, alcoholic and aqueous extracts of sample at the same concentrations utilized for the standard solution of gallic acid.

The reading was performed with spectrophotometer Model SP-220, brand Biospectro at 750nm.

\section{Results}

\section{Chemical composition}

Table 1 shows the results found by analyzing the chemical composition of $A$. sylvaticus dehydrated mushroom. One can observe the high protein content (41.16\%), followed by carbohydrates $(36.21 \%)$.

Table 2 shows values found for rating minerals in dehydrated $A$. sylvaticus fungus, including iron, zinc, calcium, cobalt, magnesium, sodium, potassium, manganese and copper. It was not possible to determine the dosage of other minerals performed in the laboratory owing to operational reasons.

The quantities of liposoluble vitamins and vitamin $\mathrm{C}$ found in the mushroom A. sylvaticus are shown in Table 3. Liquid chromatography analysis enabled the analysis of vitamin $\mathrm{A}$ in acetate form, palmitate and propionate in addition to its pure form; of vitamin $\mathrm{E}$ in acetate form, alpha, beta, delta and gamma tocopherol; of vitamin $\mathrm{K}$ in the $\mathrm{K} 1$, $\mathrm{K} 2, \mathrm{~K} 3$ and $\mathrm{K} 4$ form; however, vitamin D2 was detected by titration.

\section{Antioxidant potential}

The antioxidant potential of ether, alcoholic and aqueous extracts obtained from A. sylvaticus mushroom is shown in Table 4.

\begin{tabular}{|l|l|}
\hline Constituent & Composition $(\%$ in $\mathbf{1 0 0 g})$ \\
\hline Humidity & 6.31 \\
\hline Ash & 7.38 \\
\hline Protein & 41.16 \\
\hline Lipids & 6,60 \\
\hline Carbohydrates & 36.21 \\
\hline Dietary fiber & 2.34 \\
\hline
\end{tabular}

* The chemical analysis was performed in duplicate.

* The methods of chemical analysis of dehydrated $A$. sylvaticus mushroom are described by AOAC: Moisture (kiln at $105^{\circ} \mathrm{C}$ ), ash (muffle furnace at $550^{\circ} \mathrm{C}$ ), proteins (Kjedahl), lipids (Soxhlet), Carbohydrate (difference from the other constituents of $100 \%$ ), and dietary fiber (by enzymatic digestion of the sample).

Table 1: Chemical composition of dehydrated $A$. sylvaticus.

\begin{tabular}{|l|l|}
\hline Constituent & Composition \\
\hline Iron & $726.90 \mathrm{mg} / 100 \mathrm{~g}$ \\
\hline Calcium & $1.35 \mathrm{mg} / 100 \mathrm{~g}$ \\
\hline Zinc & $549.25 \mathrm{mg} / 100 \mathrm{~g}$ \\
\hline Cobalt & $7.75 \mathrm{mg} / 100 \mathrm{~g}$ \\
\hline Magnesium & $21.19 \mathrm{mg} / 100 \mathrm{~g}$ \\
\hline Sodium & $255.34 \mathrm{mg} / 100 \mathrm{~g}$ \\
\hline Potassium & $613.03 \mathrm{mg} / 100 \mathrm{~g}$ \\
\hline Manganese & $23.18 \mathrm{mg} / 100 \mathrm{~g}$ \\
\hline Copper & $276.66 \mathrm{mg} / 100 \mathrm{~g}$ \\
\hline
\end{tabular}

*Analyses of minerals was performed by atomic absorption spectrometry.

Table 2: Evaluation of minerals in dehydrated $A$. sylvaticus.

\begin{tabular}{|l|l|l|}
\hline Vitamin & Composition & Wavelength $(\boldsymbol{\Lambda})$ \\
\hline Ascorbic acid (Vitamin C) & $12.65 \mathrm{mg} / 100 \mathrm{~g}$ & - \\
\hline Retinol acetate (Vitamin A) & $0.000 \mathrm{mg} / 100 \mathrm{~g}$ & $460 \mathrm{~nm}$ \\
\hline Retinol (Vitamin A) & $0.001 \mathrm{mg} / 100 \mathrm{~g}$ & $460 \mathrm{~nm}$ \\
\hline Retinol palmitate (Vitamin A) & $0.000 \mathrm{mg} / 100 \mathrm{~g}$ & $460 \mathrm{~nm}$ \\
\hline Propionate, retinol (Vitamin A) & $0.000 \mathrm{mg} / 100 \mathrm{~g}$ & $460 \mathrm{~nm}$ \\
\hline Vitamin D2 & $0.018 \mathrm{mg} / 100 \mathrm{~g}$ & $460 \mathrm{~nm}$ \\
\hline Tocopherol acetate (Vitamin E) & $0.000 \mathrm{mg} / 100 \mathrm{~g}$ & $295 \mathrm{~nm}$ \\
\hline Alpha tocopherol (Vitamin E) & $0.020 \mathrm{mg} / 100 \mathrm{~g}$ & $295 \mathrm{~nm}$ \\
\hline Beta Tocopherol (Vitamin E) & $0.000 \mathrm{mg} / 100 \mathrm{~g}$ & $295 \mathrm{~nm}$ \\
\hline Delta Tocopherol (Vitamin E) & $0.000 \mathrm{mg} / 100 \mathrm{~g}$ & $295 \mathrm{~nm}$ \\
\hline Gamma tocopherol (Vitamin E) & $0.000 \mathrm{mg} / 100 \mathrm{~g}$ & $295 \mathrm{~nm}$ \\
\hline Phylloquinone (vitamin K1) & $0.000 \mathrm{mg} / 100 \mathrm{~g}$ & $350 \mathrm{~nm}$ \\
\hline Menaquinone (vitamin K2) & $0.001 \mathrm{mg} / 100 \mathrm{~g}$ & $280 \mathrm{~nm}$ \\
\hline Menadione (Vitamin K3) & $0.000 \mathrm{mg} / 100 \mathrm{~g}$ & $460 \mathrm{~nm}$ \\
\hline Naftaquinone (Vitamin K4) & $0.000 \mathrm{mg} / 100 \mathrm{~g}$ & $350 \mathrm{~nm}$ \\
\hline
\end{tabular}

* The analysis of liposoluble vitamins was performed in duplicate, using liquid chromatography of the oil obtained from the lipids' analysis of A. sylvaticus fungus.

* The analysis for detecting vitamin $C$ was performed in triplicate by titration from the non fractioned aqueous extract of $A$. sylvaticus mushroom.

Table 3: Composition of vitamins of $A$. sylvaticus mushroom

\section{Total polyphenols}

The amount of polyphenols detected in the ether, alcoholic and aqueous extracts are shown in Table 5.

\section{Discussion}

In this study we observed that the protein content of A.sylvaticus $(41.16 \%)$ is superior when compared to the protein content of beef (approximately 14.8\%), as well as of other mushrooms from the Agaricales family [15].

In addition to the high-protein content, protein from mushroom A. sylvaticus has high biological value, since it exhibits all the essential 
amino acids [16], as shown by research conducted by the Japan Food Research Laboratories [14] on A. sylvaticus grown in Brazil.

The following levels were detected at the time: $1.71 \mathrm{~g} / 100 \mathrm{~g}$ of arginine, $1.55 \mathrm{~g} / 100 \mathrm{~g}$ of lysine, $0.62 \mathrm{~g} / 100 \mathrm{~g}$ of histidine, $1.11 \mathrm{~g} / 100 \mathrm{~g}$ of phenylalanine, $0.83 \mathrm{~g} / 100 \mathrm{~g}$ of tyrosine, $1.72 \mathrm{~g} / 100 \mathrm{~g}$ of leucine, $1.01 \mathrm{~g} / 100 \mathrm{~g}$ of isoleucine, $0.39 \mathrm{~g} / 100 \mathrm{~g}$ of methionine, $1.28 \mathrm{~g} / 100 \mathrm{~g}$ of valine, $1.75 \mathrm{~g} / 100 \mathrm{~g}$ of alanine, $1.25 \mathrm{~g} / 100 \mathrm{~g}$ of glycine, $1,26 \mathrm{~g} / 100 \mathrm{~g}$ of proline, $5.73 \mathrm{~g} / 100 \mathrm{~g}$ of glutamic acid, $1.20 \mathrm{~g} / 100 \mathrm{~g}$ of serine, $1.21 \mathrm{~g} / 100 \mathrm{~g}$ of threonine, $2.35 \mathrm{~g} / 100 \mathrm{~g}$ of aspartic acid, $0.43 \mathrm{~g} / 100 \mathrm{~g}$ of tryptophan and $0,36 \mathrm{~g} / 100 \mathrm{~g}$ of cystine.

Because they are high-protein food, mushrooms are highly recommended for those who need a high protein diet, or for those whose diet has restrictions on lipids. This fact is of great importance regarding public health, since research reveals that the Brazilian population includes a large number of overweight or obese individuals. This is certainly already causing public health concern, upon considering a population whose consumption profile has considerably changed, especially during the 80 's, due to economic factors and the related social consequences [18].

According to results on the amounts of protein and lipids in the present study, A. sylvaticus mushroom can also be suggested as an important alternative health food.

In the 2005 survey conducted by the Japan Food Research Laboratories on the A Sylvaticus grown in Brazil, values found for dehydrated mushroom were $4.4 \mathrm{~g} / 100 \mathrm{~g}$ of moisture, $39.4 \mathrm{~g} / 100 \mathrm{~g}$ of protein, $3.0 \mathrm{~g} / 100 \mathrm{~g}$ of lipid, $45.6 \mathrm{~g} / 100 \mathrm{~g}$ of carbohydrate and $7.6 / 100 \mathrm{~g}$ of minerals. Comparing the above results with the present study, $A$. sylvaticus mushroom grown in Brazil in 2010 in dried state, shows higher values of moisture content $(6.31 \%)$, lipids $(6.60 \%)$ and protein $(41.16 \%)$, which can be explained if taking into account differences in farming technique, region, climate, genetic mutations [3], conditions which are probably better in the areas where the mushroom is currently cultivated.

In a study by Copercon, cited by Eira [19], the chemical composition of other mushrooms of the genus Agaricus, A. brasiliensis in dried state, showed the following results: water $(7.5 \%)$, protein $(36.6 \%)$, lipids (3.4\%), fiber (6.8\%), ash (7.3\%), and carbohydrates (38.3\%). Comparing these results with those of the present work, we see that only the ash content of the fungi studied was similar.

The present study revealed $2.34 \%$ value of dietary fiber. According to Novaes and Novaes [15], the dietary fibers contained in mushrooms

\begin{tabular}{|l|l|}
\hline Extract & Antioxidant potential (\%) \\
\hline Alcoholic & 75.6 \\
\hline Ethereal & 14.6 \\
\hline Aqueous & 14.6 \\
\hline
\end{tabular}

* The antioxidant potential of $A$. sylvaticus mushroom was observed from spectrophotometric analysis of three extracts from the sample. As oxidant we used the DPPH as standard.

Table 4: Antioxidant potential of ether, alcoholic and aqueous of $A$. sylvaticus fungus extracts.

\begin{tabular}{|l|l|}
\hline Extract & Total polyphenols (\%) \\
\hline Ethereal & 4.11 \\
\hline Alcoholic & 9.43 \\
\hline Aqueous & 0.98 \\
\hline
\end{tabular}

* Total polyphenols research was performed using the Folin-Ciocalteou in spectrophotometer at $750 \mathrm{~nm}$.

Table 5: Quantification of total polyphenol of ether, alcoholic and aqueous extracts of $A$. sylvaticus fungus. can absorb toxic, harmful and carcinogenic substances. Countless studies show fibers being associated to lower incidence of colorectal cancer, since it accelerates faecal excretion by laxative action, reducing the time spent in the intestines.

With respect to the lipid content, we detected $6.60 \%$ of this nutrient in the A. sylvaticus fungus. According to Borchers et al. [20], although mushrooms contain small quantities of total fat, they have a high percentage of polyunsaturated fatty acids (PUFA) and low content of saturated fatty acids and cholesterol. According to Novaes and Novaes [15], crude fat mushrooms consists of several classes of lipids, including free fatty acids, mono- di- and triglycerides, sterols, terpenoids and phospholipids, especially lecithin.

The Japan Food Research Laboratories also performed analysis of sodium $(4.2 \mathrm{mg} / 100 \mathrm{~g})$, iron $(21.2 \mathrm{mg} / 100 \mathrm{~g})$, calcium $(35.7 \mathrm{mg} / 100 \mathrm{~g})$, potassium $(3.15 \mathrm{mg} / 100 \mathrm{~g})$ magnesium $(100 \mathrm{mg} / 100 \mathrm{~g})$, copper $(8.24$ $\mathrm{mg} / 100 \mathrm{~g})$, zinc $(6.61 \mathrm{mg} / 100 \mathrm{~g})$, manganese $(0.65 \mathrm{mg} / 100 \mathrm{~g})$, selenium $(36 \mu \mathrm{g} / 100 \mathrm{~g})$, and cobalt $(0.13 \mathrm{ppm})$. Neither molybdenum nor boron was detected. Comparing these results with this study, we can observe the discrepancy between results for the most researched minerals, which come in higher concentrations in this work. According to Urben [3], this variation in minerals can also be explained by the type of crop, climate, region, and genetic mutations, among others, found more favorable in techniques used at present to cultivate the genus $A$. sylvaticus mushroom.

According to [16], mushrooms have significant amounts of sodium. The presence of potassium, calcium, phosphorus, magnesium, iron and zinc was also observed by Borchers et al. [20].

In a study by Copercon, cited by Eira [19], the mineral composition of the dehydrated mushroom $A$. brasiliensis showed the following results for phosphorus, iron and calcium: $939 \mathrm{mg} / 100 \mathrm{~g}, 18.2 \mathrm{mg} / 100 \mathrm{~g}$ and $41.6 \mathrm{mg} / 100 \mathrm{~g}$, respectively.

Olivera et al. [18], studying the fungus A. blazei, found high levels of minerals such as potassium (2.34\%), phosphorus $(0.87 \%)$, calcium (0.07\%), magnesium $(0.08 \%)$, sulfur $(0.29 \%)$, copper $(61.88 \mathrm{mcg})$, zinc (86.90 mcg), iron $(79.63 \mathrm{mcg})$.

Among the vitamins exhibited by $A$. sylvaticus surveyed by the Japan Food Research Laboratories in 2005, the following substances were not detected in the sample: $\alpha$-carotene, $\beta$-carotene and Vitamin C. However, values found were $1.21 \mathrm{mg} / 100 \mathrm{~g}$ of thiamine (Vitamin B1), $3.41 \mathrm{mg} / 100 \mathrm{~g}$ of riboflavin (Vitamin B2), $0.83 \mathrm{mg} / 100 \mathrm{~g}$ of Vitamin B6, $0,17 \mu \mathrm{g}$ of Vitamin B12, $5,8 \mu \mathrm{g}$ of calciferol (Vitamin D), $0.36 \mathrm{mg} / 100 \mathrm{~g}$ of folic acid, $39.4 \mathrm{mg} / 100 \mathrm{~g}$ of pantothenic acid, inositol $201 \mathrm{mg} / 100 \mathrm{~g}$ and $39.9 \mathrm{mg} / 100 \mathrm{~g}$ of niacin.

As seen in Table 3, vitamin C was detected in samples of A. sylvaticus analyzed in this study, which disagrees with the results presented by the Japan Food Research Laboratories [17]. According to Lederer [21], the importance of vitamin $\mathrm{C}$ is associated with several types of cancer, and daily doses administered to patients with cancer have improved their survival.

Among the surveyed liposoluble vitamins, alpha tocopherol within the D complex, retinol, within the A complex and menaquinone from K Complex were detected. According to Soares [22], the accumulation of these compounds is dependent on the handling, processing and maturity of mushroom at harvest.

Because they are obtained synthetically, tocopherol acetate and retinol acetate were not detected in samples of dehydrated $A$. sylvaticus mushroom. According to Borchers et al. [20], mushrooms contain 
significant amounts of niacin, thiamin, riboflavin, biotin, ascorbic acid and pro-vitamins A and D. According to Eira and Braga [23], knowledge of the chemical composition of mushrooms is very important, and in Brazil the genetic and physiological studies, basic and applied, can be expanded aiming at selecting more stable and productive lineages, establishing more appropriate physiological conditions for the cultivation of mushrooms so as to attain the desired standard of quality.

According to Silva et al. (24), despite the high biodiversity of mushrooms found in Brazil and great exploitation potential, there is little data on the antioxidant activity of mushroom extracts, since antioxidants have the ability to scavenge free radicals, which are harmful to human health [25].

Antioxidants are able to slow oxidation rate, inhibiting free radicals and preventing the onset of diseases, thus contributing to greater longevity, making the balance between free radicals and the antioxidant defense system essential [26].

Clinical and experimental studies demonstrate that dietary supplementation with Agaricales mushrooms and other medicinal fungi exert positive nutritional, medicinal and pharmacological effects and can be used as an adjuvant in cancer therapy. The mechanisms of action of bioactive compounds found in mushrooms are yet to be fully elucidated in the literature, but scientific evidence suggests that these substances are able to modulate carcinogenesis not only at early stages, but at more advanced phases of disease progression as well, providing benefits to individuals with various types of cancer, mainly by stimulating the immune system [27].

Regarding antioxidant activity it was observed that the alcoholic extract of the mushroom A. sylvaticus has great antioxidant potential (74.6\%), suggesting that most antioxidant compounds present in this mushroom can be more easily diluted in alcohol. However, the aqueous and ether fractions showed lower antioxidant potential (14.6\% each) when compared to alcoholic fraction. The aqueous fraction presented reduced antioxidant potential (14.6\%) compared to results reported by Percario et al. [28] for the fungus in liquid suspension (50\%), since in this work, antioxidant compounds had already been extracted by ether and by alcohol.

Polyphenols make a heterogeneous group, composed of several classes of substances with antioxidant capacity, among which phenolic acids and flavonoids stand out. The antioxidant activity of polyphenols is mainly due to its reducing properties, whose intensity of antioxidant activity exhibited by these phytochemicals is notably differentiated because it depends fundamentally on the number and position of hydroxyl groups present in the molecule [29].

In this study we determined the amount of total polyphenol for the etheric, alcoholic and aqueous extracts. We noticed that the largest amount of alcoholic extract is concentrated in polyphenols $(9.43 \mathrm{mg} / 100 \mathrm{~g})$ followed by etheric extract $(4.11 \mathrm{mg} / 100 \mathrm{~g})$, and aqueous extract $(0.98 \mathrm{mg} / 100 \mathrm{~g})$. The use of ethanol made possible the extraction of a higher content of polyphenols, since the alcoholic extract of the A. sylvaticus sample exhibited higher total phenolic content than the aqueous and ethereal which hold lower levels of these constituents.

Aiming to evaluate the antioxidant capacity of the A. sylvaticus mushroom in different forms of preparation (liquid suspension, fresh, dry and tablets), Percario et al. [28] assessed the ability of samples to inhibit in vitro the formation of free radicals by ABTS (2,2-azinobis3-ethylbenzothiazoline-6-sulfonic acid-diamonic) over a period of 90 seconds, resulting in decreased absorbance at $600 \mathrm{~nm}$. The authors observed excellent antioxidant activity (\%) in all forms of preparation of
A. sylvaticus at concentrations of $1 \mathrm{mg}$ sample. The authors emphasized that the temperatures used in the preparation of the samples were $60^{\circ} \mathrm{C}$ for the dried mushroom and liquid suspension, since high temperatures can inactivate most molecules with antioxidant properties present in $A$. sylvaticus According to the authors, these molecules are easily degraded when exposed to industrial processes, which reduces their antioxidant capacity. According to Barros et al. [30], the cooking processes are responsible for the reduction of nutrients with antioxidant capabilities in several mushrooms analyzed in Portugal.

Percario [28] researched different molecules with antioxidant capacity in A. sylvaticus fungus, and found results of $72 \mathrm{mg} / \mathrm{g}$ for $\beta$-Glucan in the liquid suspension and $14.1 \mathrm{mg} / \mathrm{g}$ in tablet form. For flavonoids, values of $0.88 \mathrm{mg} / \mathrm{g}$ were found in liquid suspension and $0.63 \mathrm{mg} / \mathrm{g}$ in tablet form. For total phenols, values were $0.1 \mathrm{mg} / \mathrm{g}$ for liquid suspension and $3.4 \mathrm{mg} / \mathrm{g}$ for tablet form. The author suggested that the antioxidant activity of $A$. sylvaticus mushroom is due to the entirety of molecules it contains, and not a specific component only.

In a study performed by Silva et al. [24] the antioxidant potential of different extracts of the mushroom A. blazei was evaluated by the DPPH method. The authors also observed a higher antioxidant activity (28.6\%) in methanol extract: aqueous (1:1), with extraction time of six hours. Results displayed in the present work, confirmed that the best antioxidant activity for Agaricus sylvaticus extract was in the alcoholic fraction $(74.6 \%)$, which shows that components with antioxidant properties of this mushroom are more easily soluble in alcohol.

Some authors utilized the researched mushroom extracts as ingredients in some foods in order to find out the antioxidant effect in processed products. Silva et al. [24] added the methanol: water extract $(1: 1)$ to soybean oil and obtained good results. Results showed effective protection (20.4 h of oxidative stability), and the activity of A. blazei extract was more efficient than the synthetic antioxidant BHT $(100 \mathrm{mg} /$ $\mathrm{kg}$ ) and less efficient than the TBHQ (50mg/kg).

Silva et al. [24], evaluating the A. blazei mushroom, obtained concentration of $15 \mathrm{mg} / \mathrm{g}$ of total phenolic compounds in methanol extract: water extract (1:1). The content of total phenolic compounds present in A. blazei was also assessed by Tsai et al. [7], who obtained $5.67 \mathrm{mg} / \mathrm{g}$ of phenolic compounds in the aqueous extract of this mushroom. In this study, the values of total polyphenols were lower. The alcoholic extract of the mushroom A. sylvaticus showed $9.43 \mathrm{mg} / 100 \mathrm{~g}$ of phenolic compounds. The aqueous and ether extracts showed 4.11 and $0.98 \mathrm{mg} / 100 \mathrm{~g}$ respectively.

\section{Conclusion}

Through this study we were able to observe the rich chemical composition of A. sylvaticus, highlighting the variety and quantity of minerals and the high protein content of this mushroom. It was also found that the chemical composition of the mushroom showed differences when compared to the composition of the same mushroom in other studies and other mushrooms of the Agaricales genus.

It was also observed the great antioxidant potential of aqueous, alcoholic and ethereal extracts of the A. sylvaticus mushroom, emphasizing the alcoholic extract, which demonstrated the extraordinary benefits of this mushroom in diet, considering that antioxidants prevent against premature aging and various types of cancer.

\section{References}

1. Furlani RPZ, Godoy HT (2005) Nutritional value of edible mushrooms. Revista do Instituto Adolfo Lutz 64: 149-154. 
Citation: Costa JV, Garbi Novaes MRC, Asquieri ER (2011) Chemical and Antioxidant Potential of Agaricus sylvaticus Mushroom Grown in Brazil. J Bioanal Biomed 3: 049-054. doi:10.4172/1948-593X.1000042

2. Valentão P, Andrade PB, Rangel J, Ribeiro B, Silva BM, et al. (2005). Effect of the conservation procedure on the contents of phenolic compounds and organic acids in chanterelle (Cantharellus cibarius) mushroom. J Agric Food Chem 53: 4925-4931.

3. Urben AF (2007) Morphological and physiological access of Agaricus blazei and $A$. sylvaticus. Biotechnology Science and Development 37.

4. Barros L, Baptista P, Correia DM, Morais JS, Ferreira IC (2007) Antioxidan activity of Portuguese wild edible mushrooms. Journal of Agricultural and Food Chemistry 55:4781-4788.

5. Cheung LM, Cheung PCK, Ooi VEC (2003) Antioxidant activity and total phenolics of edible mushroom extracts. Food Chemistry 81: 249-255.

6. Elmastas M, Isildak O, Turkekul I, Temur N (2007) Determination of antioxidant activity and antioxidant compounds in wild edible mushrooms. Journal of Food Composition and Analysis 20: 337-345.

7. Tsai S, Tsai H, Bad J (2007) Antioxidant properties of Agaricus blazei, Agrocybe cylindracea and Boletus edulis. Lebensmittel Wissenschaft und Technologie Food Science and Technology 40: 1392-1402.

8. AOAC - Association of Official Analytical Chemists (1995) Official Methods of Analysis. $16^{\text {th }}$ edition USA.

9. AOAC - Association of Official Analytical Chemists (1993) Peer Verified Methods Program, Manual of Policies and Procedures AOAC International: Arlington, VA.

10. AOAC - Association of Official Analytical Chemists (1997) Official Methods of Analysis of AOAC International. $16^{\text {th }}$ edition Gaithersburg: USA.

11. AOAC - Association Official Analytical Chemists (2002) Official Methods of Analysis of the Association Chemist $20^{\text {th }}$ edition Washington.

12. Borguini RG (2006) Antioxidant potential and physical-chemical characteristics of organic tomato (Lycopersicon esculentum) in comparison with conventional tomato. São Paulo: USP, Tese (Doutorado) - Programa de Pós-Graduação em Saúde Pública, Universidade de São Paulo, São Paulo.

13. Brand-williams W, Cuvelier ME, Berset C (1995) Use of a free radical method to evaluate antioxidant activity. Lebensmittel - Wissenschaft und-Technologie 28: 25-30.

14. Singleton VL, Rossi JA (1965) Colorimetry of total phenolics with phosphomolybdic-phosphotungstic acid reagents. American Journal of enology and Viticulture 20: 144-158.

15. Novaes MRCG, Novaes LCG (2005) Pharmaco-Nutrients in edible mushrooms and other basidiomycetous Agaricales. Journal of Clinical Nutrition 20: 181187.

16. Mala A (2002) Importance of using mushrooms: nutritional and medicinal. Rio de Janeiro: Embrapa 143-161.
17. JAPAN. Japan Food Research Laboratories. http://read.jst.go.jp/index_e.html

18. Oliveira MW, Oliveira ER, Lima LCO, villas boas EVB (1999) Proximate composition of mushroom (Agaricus blazei) III Simpóssio Latino Americano de Ciências dos Alimentos, November, 1999 - Campinas - SP. R. Universidade de Alfenas, Alfenas, 5: 169-1172.

19. Eira AF (2003) Cultivation of medicinal mushroom Agaricus blazei (Murrill) ss.Heinemann or Agaricus brasiliensis (Wasser et al.).Viçosa: Easy to Learn 398.

20. Borchers, AT, Stern JS, Hackman RM, Keen CL, Gershwin ME (1999) Mushrooms, tumors, and immunity. Proc Soc Exp Biol Med 221: 281-293.

21. Lederer J (1990) Food and cancer $3^{\text {rd }}$ edition, São Paulo: Malone Two.

22. Soares AA (2007) Atividade antioxidante e compostos fenólicos do cogumelo Agaricus blazei Murrill. Maringá: UEM, 2007. Dissertação (Mestrado) Programa de Pós-Graduação em Ciências Biológicas, Universidade Estadual de Maringá-PR, Maringá.

23. Eira AF, Braga GC (1997) Manual do cultivo teórico e pratico do cultivo de cogumelos comestíveis, Fundação de Estudos e Pesquisas Agrícolas Florestais. 34-36.

24. Silva AC, Oliveira MC, Del re PV, Jorge N (2009) Use of mushroom extracts as natural antioxidant in soybean oil. Science and Agrotechnology 33: 1103-1108.

25. Dorman HJ, Kosar M, Kahlo K, Holm Y, Hiltunen R (2003) Antioxidant properties and composition of aqueous extracts from Mentha species, Hybrids, Varieties, and Cultivars. Journal of Agricultural and Food Chemistry 51: 4563-4569.

26. Ferreira LA, Matsubara LS (1997) Free radicals: concepts, related diseases, defense system and oxidative stress. Revista Associação Médica Brazileira 43: 61-68.

27. Fortes RC, Novais MR (2006) Efeitos da suplementação dietética com cogumelos Agaricales e outros fungos medicinais na terapia contra o câncer Revista Brasileira de Cancerologia 52: 363-371.

28. Percário S, Naufal AS, Gennari MS, Gennari JL (2009) Antioxidant activity of edible mushroom blushing wood, Agaricus sylvaticus Schaeff. (Agaricomycetideae) in vitro. International Journal of Medicinal Mushrooms 11: 133-140.

29. Kaur C, Kapoor HC (2002) Anti-oxidant activity and total phenolic content of some Asian vegetables. International Journal of Food Science and Technology 37: 153-161.

30. Barros L, Baptista P, Correa MD, Mitchell JS, Ferreira IC (2007) Effects of conservation treatment and cooking on the chemical composition and Antioxidant activity of Portuguese wild edible mushrooms. J Agric Food Chem 55: $4781-4788$ 